\title{
Entrepreneurship in the rural areas of Romania. The impact of the 2007-2013 EU funding programmes
}

\author{
Mihaela-Cornelia DAN \\ The Bucharest University of Economic Studies, Bucharest, Romania \\ mihaela.dan@fabiz.ase.ro \\ Claudia POPESCU \\ Agency for Rural Investment Funds, Bucharest, Romania
}

\begin{abstract}
This paper contributes to the research on entrepreneurship in rural areas by focusing on the absorption and investment plans developed with European Funds and implemented in Romania in 2007-2013 for rural development. Entrepreneurship in the European Union is seen as the solution for creating and increasing jobs number, developing new business models, and is related very often with creativity and innovation. Moreover, entrepreneurship is directly linked to the economic performance of regions (Audretsch, D.B., Keilbach, M., 2005), poverty reduction and contributes to the economic advancement of rural communities. The focus on rural areas is given by the fact that almost half of the Romanian population lives in villages or communes (around 45\%), and the main income source comes from agriculture. In the same time, there is an important potential for entrepreneurial projects because rural areas are high underdeveloped, there is a lack of services in major fields as education, social services, entertainment etc. Also, we find a high potential in tourism, especially in ecological, adventure or agro-tourism. We develop a theoretical framework to discuss the potential impact of EU Funds on rural development, the access to public funds for rural population, their readiness for business ownership, the most accessible fields for starting a business and regional variables. Our study is based on public data and official reports on the European Funds received by Romania in the budgetary period of 2007-2013 and other market data that round the entrepreneurship frame in rural areas. We analyze the number of start-ups financed by European funds, type and size of enterprises, number of jobs and reasons for contract cancellation. We find that regions with a reach cultural heritage and closer to the Western border have registered more applications and are more interested in self-employment, but also that given the administrative barriers many entrepreneurs decided to cancel the contracts.
\end{abstract}

Keywords: entrepreneurship, rural areas, European Funds, regional development, services, tourism.

\section{Introduction}

The economic and financial crisis from 2007 brought again under discussion the role of new business in the economy, the possibilities offered through entrepreneurship. One important sector where the New Member States are still behind is agriculture and the entrepreneurial initiatives for development in rural areas.

European Union gives the necessary leverages for a modern agriculture through the Common Agriculture Policy. One important funding instrument is the European Rural Development Programme (ERDP), which is translated by each Member State into the National Rural Development Programme (NRDP). Romania decided to focus on three priority areas: competitiveness promotion and restructure of the agricultural sector, environmental protection and climate change, economic development, job creation and a better life quality in villages. One of the objectives is to help the development of small farms, help farmers to diversify in non-agricultural activities, entrepreneurs to start-up, and invest in needed services for a better quality of life. Examples of supported activities are: service activities (bed and breakfast, trainings on farms); craft activities (production 
of handmade or local origin products); producing alternative energy sources and trade activities (e.g. stores attached to farms). Further, financial help is provided to entrepreneurs willing to set up new enterprises in non-agricultural areas and thus contributing to the creation of employment opportunities. Romania has a high potential in tourism, the various landscapes are an attraction for tourists that seek wild forests, preserved traditions and diverse sightseeing's.

In 2012 European Union launched the "Entrepreneurship 2020 Action Plan" and

PICBE | 1130 set out a renewed vision and actions to be taken for developing "entrepreneurial education and training, creating the right business environment and role models and reaching out to specific groups" (EC, 2012a).

One of the many reasons for this renewed approach on entrepreneurship is the fact that according to the 2012 Eurobarometer the share of people preferring selfemployment dropped since 2004 in all EU Member States, and today only 37\% of the EU population considers self-employment as the first choice (EC, 2012b)

Also, potential entrepreneurs criticize the tough environment, the lack of entrepreneurial education, the difficult access to funds, loans and markets and moreover, the bureaucracy and administrative procedures, especially when using European money (EC, 2011).

The new Member States are facing the same situation even more, because they include the majority of the less developed regions with rural areas and low income populations.

For this study we make an analysis of the ex-post results of the NRDP in Romania in the time period 2007-2013. We focus on rural entrepreneurship, on the evolution of the applications and selection process, types of activities, number of jobs created and success rate of the funded projects.

\section{Short literature review on rural entrepreneurship}

Rural Entrepreneurship is a complex concept and is defined mainly as entrepreneurship emerging in rural areas (Kalantaridis, 2006). But other researchers (Pato, Teixeira, 2016, Korsgaard, et.all, 2015, North and Smallbone, 2004) tend to look at rural entrepreneurship only as a different place for entrepreneurial activities (urban vs. rural location).

In reality, rural areas reveal other types of opportunities, the actions have different constraints and the entrepreneurial process is different. According to Stathopoulou et.all (2004), rurality shows some characteristics that affect directly the entrepreneurial milieu in these areas. They mention the physical environment (location, natural resources and landscape). The distance and proximity to big markets is influencing the transaction costs and many rural companies are not competitive and do not have access to a mobile labor force. The second factor is the social environment; traditionally rural areas have a high social capital and people tend to imitate the behavior of their neighbors more than in societies with a low social capital. The rich cultural heritage offers opportunities for valorization, exploiting the local potential, adding value by using local origin products or emphasizing the regional identity of the products. The last important factor is the economic environment. Elements that affect rural entrepreneurship are infrastructure, the existence of business networks and the use of ICTs. A less developed infrastructure can reduce the attractiveness of an area, the access to markets or the logistic process. The usage of ICTs and internet access influences the knowledge sharing and information updates.

Huggins et. al (2015) find that entrepreneurship in rural areas is influenced by 
spatial and place-based nature of the nature of markets, existence of innovation systems and local culture and communities. He argues that in order to avoid limitations and failings it is necessary to establish proper policies and support mechanisms.

\section{Rural entrepreneurship in Romania}

After the EU accession, Romania became part of the projects and funding schemes PICBE |1131 designed to help the poor regions in the development process. As mentioned before one important funding scheme is the National Rural Development Program (in Romanian: Programul National de Dezvoltare Rurala - PNDR). In the budgetary period 2007-2013 Romania received 8,022bn EUR and distributed the EU money as follows: 45\% for the 1 . Pillar - Increase of competitiveness in agriculture and forestry, 2. Pillar - Environment improvement in rural areas (25\%) and the 3. Pillar - Life quality and economic diversity in rural areas (30\%).

\section{Characteristics of the rural areas in Romania}

Romania has a surface of $238.000 \mathrm{sqkm}$ and a population of 20 million inhabitants (55\% leave in urban areas, and $45 \%$ in rural areas). It includes $6 \%$ of the European Union surface and $4 \%$ of its population.

It is known and recognized (MADR, 2014) that Romania needs high investments and a competitiveness increase in order to accelerate the economic growth and an income convergence by the European norms.

The rural areas in Romania have a high development potential. In 2012, the rural areas included a surface of $207.520 \mathrm{sqkm}$. The rural population is distributed uneven in Romania. Three regions have a rural population majority - South-Muntenia (58,6\%), North-East (56,8\%), South-West Oltenia (51,9\%); the highest density besides the region Bucuresti-Ilfov is in North-East region $(63,24 \mathrm{inh} . / \mathrm{sqkm})$, while in the Western part of the country we find an density of 26,51 inh./sqkm. These disparities influence directly the socio-economic development of the region and the life quality of the rural population.

Due to the implications of the financial crisis in 2007, Romania registered important fluctuations in the GDP. After an economic growth of $+7,8 \%$ between 2006 2008 , the GDP dropped at $-7,1 \%$ in 2009 . In 2010 as a consequence of the budgetary reduction the GDP increased to $-0,8 \%$. Starting with 2011 the GDP growth is showing a positive evolution, in $2011+1,1 \%, 2012+0,6 \%, 2013+3,4 \%$ and in $2014+2,9 \%$ (NIS, 2016).

\section{Rural entrepreneurship in Romania}

In the process of regional development in the EU, the European Commission adopted in 2006 the National Policy for Rural Development as a general frame for the Member States and funds accession. Because Romania includes the less developed regions of the $\mathrm{EU}$, the government expanded the funding programmes to various areas and objectives and concentrated on the following measures. These are:

111 “Vocational training and information actions”, 112 „Financial help for young farmers”, 121 “Modernization of agriculture holdings ”, 122 „Improving the economic value of forests", 123 "Adding value to agriculture and forestry products", 125 „Improvement and development of agriculture and forestry infrastructure”, 141 „Support the semi-subsistence farms”, 142 "Starting up producers groups”, 143 „Consultancy services for farmers”, 221 „First afforestation of agriculture land”, 211 
„Support for the underdeveloped mountain area”, 212 „Support for underdeveloped areas - other than mountain areas”, 214 „Agro-envirnoment payments”, 215 „Animals well-being”, 312 „Support for business creation and development”, 313 „Encouragement of tourism activities”, 322 „Village renewal and development, enhancement of rural heritage”, 4.1 „Implementation of local development strategies”, 421 "Implementation of co-operation partnerships", 431.1 „Building public-private partnerships”, 431.2 „Local Action Groups - competencies and local actions”, 511 „Technical Assistance ” and 611 „Direct complementary payments”.

The focus on rural entrepreneurship was mainly highligted in the 3. Pillar - Life quality and economic diversity in rural areas, Measures 312 „Support for starting and developing micro-enterprises” (M312) and 313 „Encouraging tourism activities” (M313).

The objective of Measure 312 is the sustainable development of rural economy by encouraging non-agriculture activities, increasing job numbers and supplimentary income. Start-ups but also existing micro-enterprises are eligible, where the owners can invest in handcraft activities, artisanry, marketing local products, services for the rural population or investments in renewable energy (including equipment acquisition for renewable energy other than biofuels).

Because of administrative and financial reasons Romania did not spend all the budget in the time frame of 2007 - 2013, so after negotiations with the European Commission, we received the permission to expand the programme till December 2015. Therefore the analyzed data will refer to the extended time period of 2007-2015.

There were seven call sessions for the mentioned measures with a total of 9.499 projects and a value of 1,3 billion EUR. After the selection process, only 2.693 applicants signed the funding contract; this represents 26,69\% of the PNDR target of 10.091 projects and a value of 598.788.790 EUR. In Table 1 we observe that after the selection process 4.188 projects were selected, but because of several reasons, only half decided to ask for the funds.

Table 1. Evolution of applications, selection process and signing contracts between 2007 - 2013 (M312)

\begin{tabular}{|l|c|r|r|r|r|r|r|}
\hline Year & \multirow{2}{*}{ Session } & \multicolumn{2}{|c|}{ Applications } & \multicolumn{2}{c|}{ Selected projects } & \multicolumn{2}{c|}{ Signed contracts } \\
\cline { 3 - 8 } & & Number & $\begin{array}{c}\text { Value (tsd. } \\
\text { EUR) }\end{array}$ & Number & $\begin{array}{c}\text { Value } \\
\text { (tsd.EUR) }\end{array}$ & $\begin{array}{c}\text { Numbe } \\
\text { r }\end{array}$ & \multicolumn{1}{c|}{$\begin{array}{c}\text { Value } \\
\text { (tsd.EUR) }\end{array}$} \\
\hline \multirow{2}{*}{2008} & $\begin{array}{c}18.09- \\
30.10 .2008\end{array}$ & 68 & 11321,87 & 51 & 8811,68 & 30 & 4662,14 \\
\cline { 2 - 8 } & $\begin{array}{c}17.11- \\
17.12 .2008\end{array}$ & 76 & 11062,44 & 63 & 9465,74 & 50 & 6836,27 \\
\hline 2009 & $\begin{array}{c}12.10- \\
06.11 .2009\end{array}$ & 919 & 148182,99 & 490 & 80066,46 & 378 & 60772,39 \\
\cline { 2 - 8 } & $\begin{array}{c}16.11- \\
11.12 .2009\end{array}$ & 1.137 & $165.927,55$ & 778 & $105.983,01$ & 646 & $86.856,21$ \\
\hline 2010 & $\begin{array}{c}14.06- \\
15.07 .2010\end{array}$ & 1.780 & $207.366,08$ & 975 & $107.425,69$ & 620 & $65.443,83$ \\
\hline 2011 & $02-31.05 .2011$ & 2.553 & $346.678,83$ & 908 & $89.014,08$ & 518 & $47.910,24$ \\
\hline 2012 & $03-28.09 .2012$ & 2.966 & $426.633,04$ & 923 & $134.947,15$ & 451 & $63.737,35$ \\
\hline Total & & $\mathbf{9 . 4 9 9}$ & $\mathbf{1 . 3 1 7 . 1 7 2 , 8 1}$ & $\mathbf{4 . 1 8 8}$ & $\mathbf{5 3 5 . 7 1 3 , 8 1}$ & $\mathbf{2 . 6 9 3}$ & $\mathbf{3 3 6 . 2 1 8 , 4 3}$ \\
\hline
\end{tabular}

Source: Authors' own research (MADR, 2014, AFIR, 2015).

Regarding Measure 312 „Support for business creation and development”, the statistical data show that the number of applications increased in this time period, but the number of selected projects decreased massively. In 2008 we registered only 144 applications, mainly because of the lack of information about the new programme and 
its objectives. Out of this 114 were selected, 79\% of the total projects. In 2009, were 919 applications, only $61 \%$ were selected. The situation continues in $2010-1.780$ projects, 54\% were selected, in 2011 - 2.553 projects and 35\% selected, and in 20122.966 applications and $31 \%$ selected (MADR, 2014).

The projects selected focused on start-ups $(97,62 \%)$ and the rest of the approved projects $(2,38 \%)$ included development steps for existing micro-enterprises.

The grouping according to planned activities shows that 541 projects included investments in non-agriculture activities (only 35,55\% of the PNDR target), 45 projects focused on artisanry and handcraft development (1,18\% of the PNDR target) and 2.107 projects developed services for the rural population $(46,14 \%$ of the PNDR target).

The regional distribution of the applications reveals that the region North-West is the most active and successful (546 approved projects), followed by South-Muntenia (490 approved projects) and North-East (374 projects). The region Bucuresti-Ilfov has the lowest number of projects, because the region is very urbanized and much more developed than the rest of the country.

The data presented in Table 2 show that there is a demand for investments in every region and more encouraging is the fact that citizens consider become entrepreneurs.

Table 2. The geographical distribution of the approved projects within Measure 312

\begin{tabular}{|l|c|r|}
\hline \multicolumn{1}{|c|}{ Development region } & No. of approved projects (M312) & $\begin{array}{c}\text { Public value } \\
\text { (tsd. EUR) }\end{array}$ \\
\hline North-East & 374 & $51,682.222$ \\
\hline South-East & 281 & $37,449.826$ \\
\hline South Muntenia & 490 & $59,042.203$ \\
\hline South-West & 300 & $39,052.532$ \\
\hline West & 358 & $45,920.544$ \\
\hline North-West & 546 & $61,224.695$ \\
\hline Center & 322 & $39,221.421$ \\
\hline Bucuresti-Ilfov & 22 & $2,624.989$ \\
\hline Total & $\mathbf{2 6 9 3}$ & $\mathbf{3 3 6 , 2 1 8 . 4 3 2}$ \\
\hline
\end{tabular}

A very important step in the funding process is the payment cycle, the bureaucracy (especially the requested support documents) and the number of instalments. The late payments and the delay of the business plans steps forced many entrepreneurs to cancel the contract and to stop the investments. Other reasons were contract or fiscal evasion, insolvency or bankruptcy. Between 2008 and 2015763 beneficiaries asked for contract cancellation, 472 beneficiaries did not respect the contract clauses and 10 projects were closed because other reasons. The value of the 1245 cancelled contracts is about 170 million EUR. If we take into account that these projects were financed only partially with a total sum of 15 million EUR we can conclude that one important reason for rescinding the contract was the late payment and not being able to find alternative funding sources.

Regarding the number of new created jobs, the data show results under the target of 29.494 new jobs. Between 2007-2015 7.751 new jobs were created in the rural areas of the country (only $26,28 \%$ of the national target).

The personal contribution of entrepreneurs is in general a real problem, because of the difficult access to loans. Therefor, only 45\% asked for a loan, and the rest contributed with personal financial resources or from other sources.

An interesting aspect is related to the production of renewable energy and openness to this business sectors. Around 490 micro-enterprises were founded with the 
scope to invest in and produce solar, wind and geothermal energy. The national target was exceeded with $249,94 \%$.

The scope of the second Measure 313 "Encouraging tourism activities" is to develop tourism activities and entities in rural areas, create jobs and increase the attractiveness of the rural zones. In general, the investments focused on tourism infrastructure (accommodation, entertainment), information centers, tourism maps, PICBE $\mid \mathbf{1 1 3 4}$ tourism services marketing etc.

For this measure the scheme administrators organized seven call sessions, with 3.703 projects and a value of 569.890 .750 EUR. Only 2.586 projects were selected and 1.289 signed the financing contract. This represents $46.75 \%$ of the national target, and an investments value of 358.976.990EUR (Table 3).

Table 3. Evolution of applications, selection process and signing contracts between 2007 - 2013 (M313)

\begin{tabular}{|c|c|c|c|c|c|c|c|}
\hline \multirow[t]{2}{*}{ Year } & \multirow[t]{2}{*}{ Session } & \multicolumn{2}{|c|}{ Applications } & \multicolumn{2}{|c|}{ Selected projects } & \multicolumn{2}{|c|}{ Signed contracts } \\
\hline & & Number & $\begin{array}{l}\text { Value (tsd. } \\
\text { EUR) }\end{array}$ & Number & $\begin{array}{c}\text { Value } \\
\text { (tsd.EUR) }\end{array}$ & $\begin{array}{c}\text { Numbe } \\
\text { r }\end{array}$ & $\begin{array}{c}\text { Value } \\
\text { (tsd.EUR) }\end{array}$ \\
\hline \multirow[t]{2}{*}{2008} & $\begin{array}{l}18.09- \\
30.10 .2008\end{array}$ & 121 & $22.571,38$ & 100 & $19.839,17$ & 41 & $7.082,93$ \\
\hline & $\begin{array}{l}17.11- \\
17.12 .2008\end{array}$ & 152 & $26.844,38$ & 122 & $23.469,43$ & 51 & $9.169,27$ \\
\hline \multirow[t]{2}{*}{2009} & $\begin{array}{l}12.10- \\
06.11 .2009\end{array}$ & 329 & $57.986,89$ & 270 & $47.119,41$ & 146 & $23.355,17$ \\
\hline & $\begin{array}{l}\text { 16.11- } \\
11.12 .2009\end{array}$ & 209 & $35.398,76$ & 142 & $25.089,53$ & 78 & $12.429,17$ \\
\hline 2010 & $01-30.07 .2010$ & 589 & $96.166,32$ & 445 & $70.663,46$ & 225 & $32.086,09$ \\
\hline 2011 & $01-31.03 .2011$ & 297 & $45.274,97$ & 213 & $31.385,66$ & 150 & $21.431,57$ \\
\hline 2012 & $\begin{array}{l}17.04- \\
16.05 .2012\end{array}$ & 2.006 & $285.648,05$ & 1.294 & $174.722,12$ & 598 & $74.313,57$ \\
\hline Total & & 3.703 & $569.890,75$ & 2.586 & $392.288,78$ & 1.289 & $\begin{array}{l}179.867, \\
78\end{array}$ \\
\hline
\end{tabular}

Source: Authors' own research (MADR,2014, AFIR, 2015).

Similar to Measure 312, the number of selected projects is lower than expected, but with better results. In 2008 81\% of the applications were selected for the next phase, in $200976 \%$, in $201075 \%$, in $201171 \%$ and in $201264 \%$. In the last phase only 1280 projects were put in practice, $74,63 \%$ of it focused on entertainment infrastructure (value of 287.364.420EUR), 24,67\% invested in "small scale infrastructure" (e.g. information centers) with a value of 69.813 .880 EUR and $0,70 \%$ focused on development and promotion of rural tourism services (value of 1.798.690EUR).

Regarding the geographical distribution, there are important differences between the Western and the South-Eastern part of the country (Table 4). Possible reasons are the tradition in tourism, the sightseeing opportunities that you find more often in the center and Western regions of Romania in comparison with the rest of the country. We refer here to the old castles, architectural vestiges, or the various landforms and the mountains. One exception is the region of North-East because it includes the middle age monasteries and churches, another important tourism attraction.

Table 4. The geographical distribution of the approved projects within Measure 313

\begin{tabular}{|l|c|r|}
\hline \multicolumn{1}{|c|}{ Development region } & No. of approved projects (M313) & $\begin{array}{c}\text { Public value } \\
\text { (tsd. EUR) }\end{array}$ \\
\hline North-East & 204 & $24.915,394$ \\
\hline South-East & 87 & $13.761,447$ \\
\hline South Muntenia & 74 & $10.826,509$ \\
\hline South-West & 121 & $18.247,553$ \\
\hline
\end{tabular}




\begin{tabular}{|l|c|r|}
\hline West & 209 & $30.062,554$ \\
\hline North-West & 333 & $45.463,086$ \\
\hline Center & 260 & $36.398,614$ \\
\hline Bucuresti-Ilfov & 1 & 192,617 \\
\hline Total & $\mathbf{1 2 8 9}$ & $\mathbf{1 7 9 , 8 6 7 . 7 7 6}$ \\
\hline \multicolumn{2}{|c|}{ Source: Authors' own research (MADR,2014, AFIR, 2015). } \\
\hline
\end{tabular}

Similar to Measure 312, also within the Measure 3131.007 contracts were PICBE| 1135 cancelled because of different reasons, such as decision of the beneficiary, contract and fiscal evasion or insolvency. Out of the cancelled contracts 729 were rescinded on beneficiary's request, 261 were invalidated because fiscal evasion and 17 because other reasons (e.g. insolvency). The total value of the cancelled contracts is 150.770.534 EUR and the payments till cancellation represented only 2 million EUR.

Overall, the targets of measure 313 were reached partially and only $46,75 \%$ of the initiatives were put in practice. The target for entertainment infrastructure and tourism accommodation was met around 45,88\%, the target for small-scale infrastructure reached $59,67 \%$ and $7,15 \%$ projects focused on development and marketing of rural tourism services. The investment value reached $78,87 \%$ of the total target of 467.000.860EUR.

Regarding the new jobs created within the Measure 313, the target reached $5,65 \%$ of the total of 13.783 new jobs.

The accommodation facilites and the entertainment infrastructure increased also the number of new tourists, at about 50.400 new tourists. But, in the same time, the average stay decreased, tourists are orientated more to short week-end trips and less expensive for their budget.

\section{Conclusions}

After presenting the results of Measures 312 and 313 within the National Programme for Rural Development we may state that the objectives were partially met. The high number of applications (13.202) shows an interest of people for rural development, but it does not take into account the origin of applicants, e.g. people leaving in cities move to villages. One of the general objectives of the national programme is to encourage start-ups in villages by the rural population. The fact that only half were selected for further steps implicates the quality of the projects, the lack of information regarding the project proposals. But the most important fact is the number of cancelled contracts, which implies administrative barriers, a poor business forecast and difficulties in the procurement process.

The type of activities chosen for business plans show a risk adversity, few projects focused on bed and breakfast activities (tourism is in many regions season sensitive), the majority decided to invest in small-scale infrastructure which does not implicate higher costs after ending the project.

This study has limits because is based only on secondary data on macroeconomic level and important elements as market studies, local demand analysis, competition or access to skilled labour force were not taken into account. Because of this, the authors decided to research further the development of rural entrepreneurship in Romania by applying primary research tools.

\section{References}

Agency for Rural Investment Fund (2015). Annual progress report on PNDR in the year 2015 . 
Audretsch, D.B., Keilbach, M. (2005). Entrepreneurship capital and regional growth, Annals of Regional Science, 39(3), 457-469.

European Commission (2011). 2011 'Business Dynamics: Start-ups, Business Transfers and

Bankruptcy', file://C:/Users/Admin/Downloads/business_dynamics_final_report_en.pdf.

European Commission (2012a). Entrepreneurship 2020 Action Plan.

European Commission (2012b). Flash EB No 354 " Entrepreneurship in the EU and beyond", http://ec.europa.eu/public_opinion/flash/fl_354_en.pdf.

Huggins, R., Morgan, B., Williams, N. (2015). Regional entrepreneurship and the evolution of public policy and governance. Evidence from three regions, Journal of Small Business and Enterprise Development, 22(3), 473-511.

Kalantaridis, C. (2006). A study into the localization of rural businesses in five European countries, European Planning Studies, 14(1), 61-78.

Korsgaard, S., Műller, S., Wittorf Tanvig, H. (2015). Rural entrepreneurship or entrepreneurship in the rural - between place and space", International Journal of Entrepreneurial Behavior \& Research, 21(1), 5 - 26.

Ministry for Agriculture and Rural Development (2014). PNDR 2007-2013, http://www.madr.ro/docs/dezvoltare-rurala/PNDR_2007-2013_versiunea septembrie2014.pdf.

National Institute of Statistics (2016). Statistical Yearbook for 2015, www.insse.ro.

North, D., Smallbone, D. (2006). Developing entrepreneurship and enterprise in Europe's peripheral rural areas: Some issues facing policy-makers, European Planning Studies, 14(1), 41-60.

Pato, M. L. and Teixeira, A. A.C. (2016), Twenty Years of Rural Entrepreneurship: A Bibliometric Survey. Sociologia Ruralis, 56. 3-28. 